\title{
DR M VIJAYAKUMAR
}

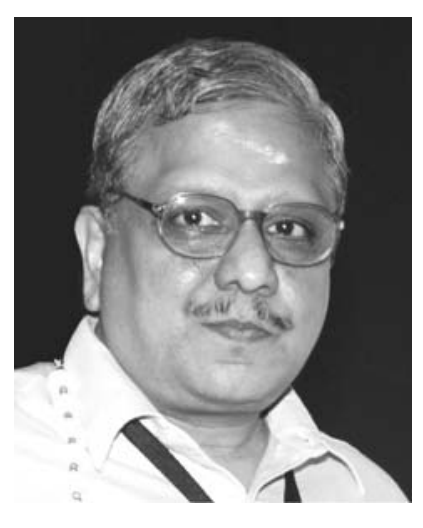

The team of Indian Journal of Practical Pediatrics submits heart felt condolences on the sudden demise of beloved past Editor-in-Chief Dr M Vijayakumar on April 21, 2017. He did his MBBS, DCH, and MD (Pediatrics) from Stanley Medical College, Chennai. He obtained his DM in Nephrology from Madras Medical College. He has also been awarded 'Fellow of Indian Academy of Pediatrics'.

He joined the Department of Pediatric Nephrology at the Institute of Child Health and Hospital for Children (ICH \& HC), Madras Medical College in 1988. He along with Prof B R Nammalwar started training the young pediatric postgraduates in the technique of peritoneal dialysis and helped save many children suffering from acute renal failure even at a time when pediatric intensive care was not that well developed. After taking voluntary retirement from government service, he did his nephrology work in $\mathrm{KKCTH}$, Chennai for some time before starting the Department of Pediatric Nephrology at Dr Mehta's Children's Hospital, Chennai in 2008. He was the Head of the Department of Pediatric Nephrology and Program Director for Pediatric Nephrology Certificate course of ISPN and Fellowship Program of Pediatric Nephrology from the Tamilnadu Dr MGR Medial University, Chennai, till his untimely death.

He was a teacher par excellence and an orator with clarity. A straight forward, sincere, hardworking but unassuming personality committed in his duties wherever he was. His contribution in teaching, community health services from Stanley Medical College, Madras Medical College and then at Dr Mehta's Children Hospital is incomparable. He had been a great guiding force to his students and colleagues both in their professional and personal life.

He had published 35 research articles in National and International journals. He was one of the editorial board members in Indian Journal of Practical Pediatrics when it was started in 1993, and his untiring work propelled him to become the Editor-in-Chief of the journal, between 1993-2001. He also served as one of the reviewers in Indian Pediatrics, and has also served in the editorial board of Asian Journal of Pediatric Practice and Indian Journal of Nephrology. He was one of the co-author of the book "Principles and Practice of Pediatric Nephrology" along with Dr B R Nammalwar. He had also been a part of the Editorial Board of IAP Textbook of Pediatrics, 1999-2001.

He served IAP as Executive Board Member of Central IAP, Office bearer of Tamilnadu State IAP (IAP - TNSB), Secretary and Treasurer of IAP Subspecialty Chapter of Pediatric Nephrology. He started the IAP Chennai City Branch in 2003 and served as its president in 2003-04. He co-authored the book "Management Guidelines of Common Pediatric Problems" which generated funds for IAP CCB. He was a faculty at many National / State / Zonal Conferences of IAP. He was the Scientific Chairman of PEDICON 2004 held at Chennai, and his time management of the sessions throughout the conference became a benchmark for subsequent IAP conferences.

He was one of the founder members of Indian Pediatric Nephrology Group of IAP in 1988 and played an important role in the group and then in the Indian Society of Pediatric Nephrology. He had served as Honorary Secretary and Treasurer of this group, and was the Organizing Secretary for Pediatric Nephrology Annual Conference at Chennai in 1991. He had been an Expert member in all the guidelines formulated by this group, from the beginning and also a resource person in all education activities of this group. He was also the Organizing Chairman, ISPNCON 2012, National Conference of Indian Society of Pediatric Nephrology supported by International Society of Nephrology and International Pediatric Nephrology Association held in Chennai in 2012. He is survived by his wife, one son and daughter. With the passing away of Dr MVK, as he is fondly called, IAP has lost one of its great teacher- and the country, a good pediatric nephrologist. We pray for his soul to rest in peace. 